\title{
Translanguaging-ikuspegia lehen hezkuntzako ikasgelan. Ba al du eraginik ikasleen euskara-mailan? ${ }^{1}$
}

\author{
Translanguaging in a primary classroom. \\ Does it have an impact on students' level of Basque?
}

\author{
Oihana Leonet* \\ Hezkuntza, Filosofia eta Antropologia Fakultatea
} $\mathrm{UPV} / \mathrm{EHU}$

LABURPENA: Translanguaging terminoan elebakartasunean oinarritutako hizkuntzen banaketarekin apurtzea proposatzen duten hainbat ekarpen teoriko nahiz praktiko biltzen dira. Ikerketa hau, ikasgela barruan, hizkuntzen artean muga zurrunik ezarri gabe, euskararen, gaztelaniaren eta ingelesaren arteko antzekotasunak nabarmentzen dituen proiektu pedagogiko handiago baten barruan gauzatu da. Zehazki, hizkuntza baliabideen erabilera alderatze hutsetik haratago joan, eta baliabide hauen erabilera estimulatzen duen eskuhartze didaktikoak ikasleen euskara mailan izandako eragina aztertu da. Ikerketa honetan Euskal Autonomia Erkidegoko ikastetxe publiko bateko 5. eta 6. mailako 89 ikaslek parte hartu dute. Ikasle guztiek euskarazko irakurriaren ulermena neurtzeko test bat gauzatu dute esku-hartzearen aurretik eta ostean. Ikasleez gain proiektuan parte hartu duen euskara irakaslearen iritziak ere jaso dira erdi-egituratutako elkarrizketa baten bidez. Emaitzek erakusten dutenez, esku-hartzeak ez du ikasleen euskara-gaitasuna kaltetu. Irakasleak ere esku-hartzearen balorazio positiboa egiten du eta translanguagingean oinarritutako esku-hartze pedagogikoa ikasleen kontzientzia linguistikoa eta metalinguistikoa indartzeko baliagarria izan dela azpimarratzen du.

GAKO-HITZAK: translanguaging, hezkuntza eleaniztuna, kontzientzia metalinguistikoa, kontzientzia linguistikoa, lehen hezkuntza

ABSTRACT: Translanguaging is an umbrella term that encompasses a variety of theories and pedagogical practices that aim at softening boundaries among languages. The current study is part of a larger research project that highlight similarities among Basque, Spanish and English and breaks with the strict separation among languages in class. The specific focus of this study is to examine the effect of the intervention on the development of the Basque language. Participants were 89 students from 5th and 6th grade of primary education from a public school of the Basque Autonomous Community. All students completed the Basque reading test before and after the intervention. Beside, a Basque language teacher who took part in the intervention participated in a semi-guided interview to gather further information about the pedagogical project. The results indicate that the pedagogical intervention based on translanguaging did not have a negative effect on students' Basque competence. Furthermore, the teacher provided a positive feedback about the intervention and highlighted the value of the materials to promote students' language and metalinguistic awareness.

KEYWORDS: translanguaging, multilingual education, metalinguistic awareness, language awareness, primary education

${ }^{1}$ Lan honek MINECO/FEDERen [EDU2015-63967-R] eta Eusko Jaurlaritzaren [DREAM IT-714-13] laguntza jaso du.

* Harremanetan jartzeko / Corresponding author: Oihana Leonet. UPV/EHU. Bilakaeraren eta Hezkuntzaren Psikologia. Hezkuntza, Filosofia eta Antropologia Fakultatea. Tolosa hiribidea, 70. E-20018 - Donostia/San Sebastián - oihana.leonet@ehu.eus https://orcid.org/0000-0002-8801-5455

Nola aipatu / How to cite: Leonet, Oihana. (2019). «Translanguaging-ikuspegia lehen hezkuntzako ikasgelan. Ba al du eraginik ikasleen euskara-mailan?»; Tantak, 31(1), 81-101. (https://doi.org/10.1387/tantak.20248).

Jasotze-data: 2018/10/08 Onartze-data: 2019/01/09.

ISSN 0214-9753 - elSSN 2444-3581 / (c) 2019 UPV/EHU

(c) (i) Obra hau Creative Commons Atribución 4.0 Internacional-en lizentziapean dago 


\section{SARRERA}

Ikuspegi elebakarretik begiratuta, hizkuntzak elementu-multzo jakin batez osatutako kode autonomoak dira; hots, hiztun eleaniztunak bere errepertorioan duen hizkuntza bakoitza entitate bereizi bat dela kontsideratzen da. Honek, jakina, ez du eguneroko bizitzan hiztun hauek egiten duten hizkuntza-erabilera islatzen. Azken urteetan elebakartasunean oinarritutako ideia honen aurrean, eredu berriak nagusitzen ari dira, bai hizkuntzen ikaskuntzaren bai eta eleaniztasunaren esparruan ere. Eleaniztasunaren literaturan jauzi nabarmena eman da. Hain zuzen ere, hizkuntzak kode-sistema autonomo eta itxiak balira bezala aztertzetik, eleaniztunengan naturalak diren hizkuntza-erabilera malguen azterketak bereganatu du arreta (Blommaert eta Rampton, 2012). Paradigma-aldaketa hau (Kramsch, 2012), noski, globalizazioaren, komunikazio digitalaren eta populazioaren mugikortasunaren fenomenoekin batera ulertu behar da (ikus, esate baterako, Conteh eta Meier, 2014; May, 2013).

Gurean, geroz eta globalagoa den gizarte honetan, gaztelaniarekin eta frantsesarekin ez ezik, hizkuntza berriekin euskarak duen kontaktuak nolabaiteko beldurra sortzen du euskararen biziberritzean eta garapenean diharduten eragile askoren artean. Eskolak paper erabakigarria izan du zeregin honetan, eta euskara babesteko beharra azpimarratzen dute irakasleek ere (Leonet, Cenoz eta Gorter, 2017). Hain zuzen ere, gurean, nazioarteko hezkuntza-sistema eleaniztun gehienetan bezalaxe, hizkuntza bakoitza modu isolatuan irakasteko joera nagusi da oraindik ere. Historikoki, hizkuntza (erregional) gutxituen biziraupena isolamendu geografikoarekin lotu izan da. Isolamendua zela eta, beste hizkuntza indartsuagoekiko kontaktua saihestu eta erosotasun handiagoz bizi izan ziren hizkuntza txikiak iraganean. Gaur egungo mundu globalizatuan, ordea, estrategia honek bere zentzua galdu du, eta hizkuntza gutxituen biziraupenerako estrategia berrien beharra azaleratu da (Cenoz eta Gorter, 2017a). Ikastetxeetan, esaterako, hainbat hizkuntza irakasteaz gain, hizkuntza gutxituaren erabilera sustatzea izan ohi dute erronka. Honek zera esan nahi du, hizkuntza bat baino gehiagotan idazten, irakurtzen eta komunikatzen ikasteaz gain, bestelako gaitasun informalak garatzeko ardura esleitzen zaiola eskolari hizkuntza gutxituak presentzia txikia duen inguruneetan. Hain zuzen ere, tokian tokiko egoera soziolinguistikoak, kasu askotan, ez die ikasleei hizkuntza gutxitua eskolaz kanpo erabiltzeko aukera bermatzen (Cenoz eta Gorter, 2017a).

Euskal Autonomia Erkidegoko (EAE) hezkuntza-sistemak hizkuntzen irakaskuntzaren esparruan duen helburu bikoitz hau abiapuntutzat hartuz, eta azken urteetan eleaniztasunaren eta hizkuntzen jabekuntzaren ikerketan gertatzen ari den paradigma aldaketarekin bat eginez, ikerlan honek ikasle eleaniztunek errepertorio linguistikoan dituzten baliabideak malgutasunez erabiltzeko aukera eskaintzen duen proposamen didaktiko bat du aztergai. Labur esanda, ikerketa honetan translanguaging-ikuspegia ikasleen euskara-maila sendotzeko helburuarekin bateragarria den ala ez aztertuko dugu. 


\section{ELEBAKARTASUNAREN HESIAK APURTZEN}

Eleaniztunon eguneroko praktikan ohikoa da hizkuntza-sistema desberdinak tartekatzea. Hizkuntza-erabilera malgu hau izendatzeko, hainbat kontzeptu garatu dira azken aldian; horien artean gehien hedatu dena translanguaging terminoa dugu.

Haren sorreratik izugarri hazi eta hedatu den terminoa da translanguaging, eta ondorioz hura azaltzeko ikuspegiak eta definizioak ikaragarri ugaritu dira azken urteetan (ikus, esate baterako, Canagarajah 2011; Cenoz eta Gorter 2017a, 2017b; Creese eta Blackledge, 2010; Cummins, 2017; García, 2009; García eta Li Wei, 2014; Lewis, Jones eta Baker, 2012a, 2012b; Otheguy, García eta Rey, 2015; Sayer, 2012). Gaur egun, egokiagoa litzateke teorizazio eta praktika adibide desberdinak biltzen dituen termino orokortzat hartzea.

Translanguagingek 80ko hamarkadako Galeseko hezkuntza-sistema elebidunean du jatorria. Galesez «trawsieithu» terminoa sortu zen ikasgela barruan bi hizkuntzen, hots, galesaren eta ingelesaren, aldibereko erabilera sistematikoa izendatzeko. Translanguaging, haren ingeleseko itzulpena, $\mathrm{da}$, hala ere, nazioartean gehien hedatu den terminoa. Williamsek proposatutako teoria pedagogiko honen arabera, ikasleek inputa hizkuntza horietako batean jasotzen dute, eta outputa, berriz, beste hizkuntzan. Horrela, translanguaging-jarduerek, hizkuntza nagusiaz baliatuz, hizkuntza ahulena garatzeko aukera eta ulermen-maila sakonagoa eskuratzeko aukera eskainiko lukete (gehiago sakontzeko, ikus, Lewis et al., 2012a, 2012b). Ideia hau azalduz, Bakerrek (2011: 288) kontzeptuaren definizio hau egin zuen: «the process of making meaning, shaping experiences, gaining understanding and knowledge through the use of two languages». Hain zuzen ere, Bakerrek dio testu bat ingelesez irakurri eta horrekin galesez beste bat ekoizteko lehenik informazio hori ulertu edo «digeritu» egin behar dela.

Aurrera jarraitu aurretik, komeni da translanguaging eta «codeswitching» terminoen arteko desberdintasunari tarte txiki bat egitea. Elkarrizketa berean hizkuntza bat baino gehiago erabiltzeari codeswitching edo kode-aldaketa deitu izan zaio (adibidez, ba igual gaur arratsaldean playara noa). Ikuspegi elebakarretik, codeswitchingak konnotazio negatiboa izan du, bi hizkuntzetan gaitasun falta izatearekin lotu baita. Honen aurrean, hainbat ikertzailek codeswitchinga eleaniztunek kontzienteki egiten dutela baieztatu ez ezik (Grosjean, 2008), euren arteko komunikaziorako tresna eraginkorra dela aldarrikatu dute (García, 2009). Li Wei eta Wu-ren (2009) arabera, codeswitchinga omen da pertsona baten elebitasun-mailaren adierazle nabarmenena. Komunikazio-era honen abantailen inguruan zabal hitz egin bada ere, oro har, codeswitchinga arbuiatu egiten da bai eskola-testuinguruan, bai eta, arrazoi politiko, sozial, kultural nahiz praktikoengatik, bestelako eremu publiko askotan ere (Arocena, Cenoz eta Gorter, 2015). 
Batez ere AEBetan, ikertzaile askok codeswitching eta translanguaging terminoak baliokideak balira bezala erabili izan dituzte. García eta Li Weik (2014), ordea, bi kontzeptuen abiapuntua desberdina dela salatzen dute. Codeswitchingek kodeen arteko alternantziari egiten dio erreferentzia, hizkuntza bakoitzari gramatika desberdin bat egotziz. Bi autore hauek defendatzen duten translanguaging-ikuspegiak, berriz, hizkuntza errepertorio bakarraren existentzia defendatzen du. Hauen antzera, Otheguy eta haren kideek (2015) berriki, «hizkuntza» konstruktuaren zilegitasuna zalantzan jarriz (xehetasun gehiagorako, ikus, García eta Li Wei, 2014), ezaugarri desberdinak integratzen dituen hizkuntza-sistema bakarra aldarrikatu dute. Horrela bada, «hizkuntza» konstruktoaren aurrean languaging eta translanguaging lehenesten dituzte (kontzeptu hauetan sakontzeko, ikus, García eta Li Wei, 2014). Otheguy eta haren kideen arabera, translanguaging elebidunen eta elebakarren, bien, diskurtsoak ulertzeko erabil daiteke: «translanguaging refers to the act of deploying all of the speaker's lexical and structural resources freely» (Otheguy et al., 2015: 297). Autore hauek sozialki eta politikoki eraikitako hizkuntza kontzeptu tradizionalaren aurrean, translanguaginga aldarrikatzen dute, hiztun bakoitzarengan bakarra den «idiolect» edo errepertorio linguistikoa bezala definituz. Horrenbestez, hiztun eleaniztunak bere errepertorio linguistikotik elementuak aukeratzen ditu, eguneroko behar komunikatiboei, eskola barruan nahiz eskolaz kanpo, erantzuteko.

Zenbait autorek, hain zuzen ere, nazioa eta hizkuntza ideologia gainditzeko beharra azpimarratu dute (ikus, laburpena, García eta Li Wei, 2014), haien iritziz ikuskera honek ez baitu egungo mundu globalaren heterogeneotasuna ulertzeko balio. Translanguagingen irakurketa hau defendatzen dutenek eleaniztunaren diskurtsoa sistema integratu bakar bat balitz bezala ulertzen dute; eta zalantzan jartzen dituzte, besteak beste, $\mathrm{H} 1$ eta $\mathrm{H} 2$, codeswitching edota transferentzia kontzeptuaren erabilera, hauek hizkuntzen banaketan oinarritzen direla argudiatuz.

Honen aurrean, hizkuntza-konstruktoa birdefinitzeko saiakera hau errealitate linguistikoan bakarrik fokatzen dela salatu du Cumminsek (2017), arreta errealitate sozialean jarri beharrean. Cumminsek onartzen du hizkuntzak konstrukto sozialak diren heinean haien arteko mugak ere arbitrarioak direla; baina aldi berean, eraikuntza sozial honek ekarpen oparoak egin dituela defendatzen du. Hori dela eta, Otheguyk eta haren kideek (2015) garatutako translanguaging-ikuskeraren eta hizkuntzen errealitate sozialaren arteko elkar ulertzearen aldeko apustua egiten du autore honek: «It is entirely possible to reconcile the construct of translanguaging, which highlights the integrated conceptual/linguistic system through which plurilingual individuals process and use language, with the social reality of different languages, understood as historical, cultural, and ideological constructs that have material consequences and determine social action» (Cummins, 2017:111). 


\section{TRANSLANGUAGING-AREN ERABILERA PEDAGOGIKOA}

Cenoz eta Gorterrek (2011, 2014), Focus on Multilingualism ereduaren bidez, hizkuntzen ikerkuntzan nahiz irakaskuntzan ikuspegi holistikoaren beharra azpimarratzen dute. Eredu honetan hiru dimentsio hauek kontuan hartzeko beharra aipatzen dute: hiztun eleaniztunaren berariazko ezaugarriak, honen errepertorio linguistiko osoa eta hizkuntzak erabiltzen diren testuinguru soziala. Labur esanda, Cenoz eta Gorterrek, eleaniztasunaren konstruktoari dimentsio linguistiko eta psikolinguistikoaz gain dimentsio soziala ere aitortzen diote. Hori dela eta, hiztunak bizi diren lekuko testuinguru soziala ezinbesteko faktorea da eleaniztasunaren fenomenoa ulertzeko. Cenoz eta Gorterrek hezkuntza sistema eleaniztunetan aski errotua dagoen hizkuntzen banaketarekin apurtzeko beharra azpimarratzen dute, hizkuntzetako curriculumak integratzea eta hizkuntzen erabilera arinagoa eginez, ikasleei beren errepertorio osoa erabiltzeko aukera eskaintzea, alegia.

Ikuspegi desberdinetatik egindako ekarpenak kontuan izanda, translanguaging bi norabide nagusitan zabaldu dela esan dezakegu: batetik, bi hizkuntza edo gehiago, denbora eta espazio berean, modu sistematikoan eta helburu didaktikoa duten jarduerak edo haien multzoa izendatzeko baliatzen dira (Lewis et al., 2012a). Bestetik, eleaniztunen hizkuntza-praktika espontaneoak aipatzeko, eta berba honek ikasgela barruan izan dezakeen espazioa aztertzeko erabiltzen da (García, 2009). Biek ala biek, oinarrian, hiztun eleaniztunen errepertorio osoa kontuan hartzen dute, eta hizkuntzen artean ezarritako mugak gainditzea dute jomuga. Translanguagingen erabilera pedagogikoa proposatzen duten ikerketak eta bestelako ekarpen didaktikoak batzuetan gertuago daude hasiera batean Galesen egindako proposamenetik, eta beste batzuetan, berriz, Garcíak gaineratutako ekarpenetik (ikus, Cenoz eta Gorter, 2015).

Cenoz eta Gorterrek (2017a) bi termino berri proposatzen dituzte translanguagingen bi muturrak izendatzeko: lehenengoak, translanguaging pedagogikoa izenekoak (pedagogical translanguaging), irakasleak berak ikasgela barruan gauzatzeko jarduera planifikatuak dira. Translanguagingen erabilpen pedagogiko hori egin daiteke, bai inputa eta outputa hizkuntza desberdinetan jaso eta erabiltzea proposatuz; bai eta ikasleen hizkuntza errepertorio osoa erabiltzeko aukera eskaintzen duten beste hainbat estrategiaren bidez ere. Esate baterako, ingelesez irakurtzen ari diren testuan euskara eta gaztelaniazko hitz sustraikideak identifikatzeko eskatuz. Bestalde, Cenoz eta Gorterrek ikasgela barruan nahiz handik kanpo ikasle elebidunen hizkuntza erabilera malgua izendatzeko, translanguaging espontaneoa (spontaneous translanguaging) erabiltzen dute. Translanguaging espontaneoa Otheguy eta haren kideek (2015) egindako translanguaging definizioaren hurbilekoa da. Cenoz eta Gorterren iritziz, eskolak kontuan izan behar du ikasleek beren artean komunikatzeko erabiltzen duten hizkuntza, 
hizkera? naturala; eta horrexegatik, ikuspegi biak, translanguaging pedagogikoa eta espontaneoa, elkarri hurbiltzeko beharra azpimarratzen dute.

Translanguaging pedagogikoaren esparruan, Galeseko hezkuntza-testuinguruan garatutako eredutik haratago joan dira adituak, eta ikasleen H1a modu antolatu eta sistematikoan erabiltzeko aukera eskaintzen duten hainbat proposamen ezagutzen ditugu egun (gaiaren errepasoa egiteko, ikus Cenoz eta Gorter, 2017b). Baina translanguaging-ikuspegiaren erabilera didaktikoa ez da H1en aldamio funtziora mugatzen, ikasle elebidunei euren errepertorio linguistiko osoa erabiliz hizkuntzen inguruan hausnartu eta haiek manipulatzen irakastea helburu duten zenbait saiakera egin dira dagoeneko nazioartean (Arteagoitia eta Howard, 2015; Lyster, Quiroga eta Ballinger, 2013; ikus, era berean, García eta Li Wei, 2014). Modu honetan ikasleen hizkuntzarekiko kontzientzia eta kontzientzia metalinguistikoa areagotu eta gaitasun komunikatiboa hobetu daitekeela uste da (Cummins, 2017).

Lyster, Collins eta Ballingerrek (2009) Kanadan lehen hezkuntzako bigarren mailan egindako interbentzio baten berri ematen digute. Han, irakasleek liburu elebidunekin lan egiten zuten, istorio bera kontatzeko bi hizkuntzak, frantsesa eta ingelesa, tartekatuz. Liburuaren pasarte bat frantsesez kontatzen zieten ikasleei, eta hurrengoa, berriz, ingelesez. Proiektuaren helburuetako bat zen irakasleak ikasleen errepertorio elebidunaz ohartaraztea. Parte hartu zuten ikasleen eta irakasleen artean proiektuarekiko jarrera positiboa topatu zutela adierazi zuten Lyster eta haren kideek, baina, gisa honetako interbentzioak abian jartzeko orduan helburu espezifikoagoak zehaztearen beharra ere azpimarratu zuten.

Kanok (2010) translanguagingen oinarritutako curriculum esperimental bat abiatu zuen. Helburua zen ikasle japoniarrek ingelesezko eta japonierazko testuen ekoizpenari lotutako antzekotasunen kontzientzia areagotzea, eta horrela, ingelesezko idazlanen maila hobetzea. Ikerketan AEBetan bizi ziren jatorri japoniarreko 12-16 urte bitarteko ikasleek parte hartu zuten. Ikasleek, astero, 90 minutuko saio bat jaso zuten sei hilabetean. Emaitzek adierazi zuten translanguaging-interbentzioak eragina izan zuela ikasleen ingeleseko produkzioetan. Gainera, ikasleak beren hizkuntza-erabileraz ohartarazteko balio izan zuen; hau da, partaideen kontzientzia metalinguistikoa areagotu egin zen esposizioaren eraginez.

\section{TRANSLANGUAGING-AREN ETA HIZKUNTZA GUTXITUEN ARTEKO OREKA}

Translanguagingaren inguruan egindako ikerketa gehienek bigarren hizkuntza bat erabiltzen den herrialde anglofonoetan jarri dute begirada (Creese eta Blackledge, 2010; García, 2009; Gort eta Sembiante, 2015; Martin-Beltrán, 2014). Aztertutako hizkuntzak inguru hauetan hizkuntza gutxituak badira ere, beren jatorrizko herrialdeetan estatus eta hiztun ko- 
puru handia dute. Adibide gisa aipa daitezke gaztelania, punjabera edota mandarinera AEBetan eta Erresuma Batuan.

«Regional minority languages» edo «hizkuntza gutxitu eta erregionalen» kasua bestelakoa da. Hizkuntza hauek eskualde jakin batzuetan hitz egiten dira, eta ez dira hizkuntza nagusia beste inongo estatutan (Extra eta Gorter, 2008). Beraz, ikuspuntu demografiko, geografiko eta funtzionaletik aztertuta, arestian aipatutako hizkuntzak baino askozaz ere ahulagoak dira; kasu gehienetan ez dago haien biziraupena ziurtatzerik ere. Adibide batzuk aipatze arren, euskara, galesera edo frisiera egongo lirateke talde honetan.

Hizkuntza gutxitu erregionalak irakasten diren hezkuntza testuinguruetan translanguagingen erabilera aztertu duten adituek iritzi desberdinak erakutsi dituzte. Otheguy eta haren kideek (2015) translanguaging -AEBetan «Spanglish» (Spanish + English) izenez ere izendatzen denalegitimatzen dute ikasleen arteko praktika diskurtsibo gisa, hots, jatorri hispaniarreko ikasleek bi hizkuntzetako baliabide linguistikoak libreki erabiltzea defendatzen dute. Goian aipatu bezala, gaztelaniaren egoera ezin da hizkuntza gutxitu eta erregionalen egoerarekin alderatu; hala ere, Otheguy eta haren kideek, euskaraz, maoriz edo hawaiieraz hitz egiten den eremuetan ere translanguaging espontaneoaren zilegitasuna babesten dute.

Osterkorn eta Vetterrek (2015), britaniera bidez irakasten zen lehen hezkuntzako eskola batean, ikasleek translanguaging-estrategiak erabiltzen zituztela ikusi zuten, ikastetxearen hizkuntza-politika elebakarrak kontrako jarrera irmoa bultzatu arren. Autore hauek gaineratu zuten hizkuntzen banaketaren aldeko jarrerek emozioen indargabetzea edo «emotional disempowerment of young speaker» eragiten zutela; eta ikasleek honen aurrean emozioak adierazteko nahiz alderdi ludikoetarako estrategiak asmatzen zituztela. Gela barruan translanguaging espontaneoaren edo codeswtchingaren erabilera topatu duten ikerlan ugari dago, eta hau ikasleen arteko nahiz irakasle eta ikasleen arteko komunikazio egoeretan gertatzen da (Arocena, 2018; Jones eta Lewis, 2014).

Translanguaging espontaneoaren aurrean, hala ere, kezka agertu dute beste askok. Euskal Herrian, esaterako, translanguaging egiteak hizkuntza gutxitua sendotu beharrean, kontrako efektua sor dezakeen ideia errotua dago, honek hizkuntza nagusia indartuko duela, alegia. Gainera, translanguaging espontaneoaren erabilerak hizkuntzaren kalitatean eragin dezakeela uste da; hau da, bi hizkuntzen nahasketaren ondorioz hizkuntza gutxitua pidgin bilaka daitekeela pentsatzen da (Zarraga, 2014). Hain zuzen ere, euskararen eremuan ikusi da, euskaraz ari direnean pertsonek translanguaging egiten badute ere, pertsona hauek berek ez dutela translanguaging egiten gaztelaniaz ari direnean (xehetasun gehiagorako, ikus Cenoz eta Gorter, 2017a).

Hizkuntzen purutasuna mantentzearen aldeko pentsamolde hau nahiko arrunta da beste eremu batzuetan ere. Jørgensen-en (2005) iritziz, elebi(dun) tasuna helburu duten guraso nahiz irakasle askok, oinarrian, ikasleek bi 
hizkuntzak puruki, beste hizkuntzaren arrastorik gabe, erabiltzea nahi izaten dute. Muskek (2010), Galeseko hezkuntza-testuinguruari erreferentzia eginez, hizkuntzak ez nahastearen aldeko jarrera irakasleengan ez ezik ikasleen artean ere aurkitu zutela aipatzen du; nahiz eta haien arteko berbaldian galesez ari zirenean ingelesaren ezaugarriak atzeman. Lewis eta haren kideek (2012a) ere hizkuntzen erabilera malguaren aurrean nolabaiteko kezka azaltzen dute. Haien arabera, translanguagingek arreta hizkuntza nagusian ezartzea ekar lezake. Jones eta Lewisek (2014), gaineratzen dute translanguaging helburu pedagogikoekin erabiltzen denean ere tentuz jokatu behar dela. Hain zuzen ere, hizkuntza nagusiak presentzia handia duen lekuetan, idatzizko testuak ingelesez irakurtzeko aukera eskaintzeak hizkuntza nagusiaren presentzia areagotzea ekar dezakeelako.

Translanguagingari egozten zaizkion arazoak, beraz, funtsean, hizkuntzen arteko estatus-desorekatik sortuko lirateke. Cenoz eta Gorterrek (2017a) behar-beharrezkotzat jotzen dute translanguagingaren erabilpena tokian tokiko ezaugarri soziolinguistikoetara egokitzea, honek hizkuntza gutxituetan eragin negatiborik izan ez dezan. Cummunisek (2007) Kanadako eskola elebidunetan gertatzen den hizkuntzen banaketa-ereduari eginiko salaketak aski ezagunak dira; hala ere, hizkuntza bakoitzarentzako espazioak sortzeko beharra aipatzen du autore honek berak. Garcíak (2009) honen harira hizkuntza gutxituak hizkuntza nagusiarekin lehiatuko ez duen eremuak sortzeko beharra azpimarratzen du modu honetan: «it is important to preserve a space, although not a rigid or static place, in which the minority language does not compete with the majority language» (García, 2009: 301). Hizkuntza gutxituak libreki eta hizkuntza nagusiaren mehatxupean egon gabe erabiltzen diren espazio hauei arnasguneak edo «breathing spaces» deitu zien Fishmanek (1991: 59). Finean, hizkuntza gutxitua nagusi den gune geografikoa litzateke; hala nola, herri edo hiri bateko auzo zehatz bat, lantegi bat edo eskola bera izan daitezke arnasgune. Eremu horietako biztanle gehienek hizkuntza gutxitua menperatzen dute eta hura normaltasunez erabiltzeko baldintzak betetzen dira:

Cenoz eta Gorterrek (2017a) eskolan hizkuntza gutxituarentzat arnasguneak sortu eta, aldi berean, translanguagingean oinarritutako pedagogia praktikak curriculumean integra daitezkeela uste dute. Xede horrekin, hizkuntza gutxituak irakasten diren testuinguru elebidun edo eleaniztunetan translanguaginga modu jasangarrian aplikatzeko zenbait printzipio proposatzen dituzte Cenoz eta Gorterrek (2017a):

- Hizkuntza gutxituak erabiltzeko arnasgune funtzionalak sortzea.

- Translanguagingaren bidez hizkuntza gutxituak erabiltzeko beharra garatzea.

- Hiztun berri eleaniztunek, dituzten errekurtso guztiez baliatuz, beren kontzientzia metalinguistikoa garatzea, horrela, hizkuntza guztiak garatzeko. 
- Hizkuntzekiko kontzientzia areagotzea.

- Translanguaging espontaneoa eta jarduera pedagogikoa lotzea.

Hizkuntza gutxitu erregionalak eta translanguagingaren erabilera pedagogikoa uztartzeari dagokionez, adibiderik ezagunenak Galesen jorratutako input eta outputerako kode desberdinen erabileraren inguruan sortutako teoria eta praktika pedagogikoak lirateke. Bestalde, Lowman, Fitzgerald, Rapira eta Clarkek (2007) ikusi zuten maoriera murgiltze-programetan ikasleei H1 (ingelesa) erabiltzeko aukera eskainiz, irakurketaidazketa (literacy)-gaitasunak hobetzen zirela; ingelesaren laguntzaz maorierazko testuen prozesamendua eta azterketa errazten baitzitzaien horrela. Bestalde, Llurda, Cots eta Armengolek (2013) katalanaren eta ingelesaren arteko adibide baten berri ematen dute. Katalunian, ingelesaren bidez irakasten zen unibertsitateko ikasgai batean, katalana erabiltzeko aukera ematen zitzaien ikasleei, kasu honetan, ingelesaren ulermena errazteko. Dena den, eremu honetan egindako ikerlana oso urria da oraindik.

\section{IKERKETAREN TESTUINGURUA ETA HELBURUA}

Ikerketa hau DREAM (Donostia Research group on Education and Multilingualism) taldeak garatutako proiektu handiago batetik atera da eta Focus on multilingualism ereduaren markoaren barruan translanguaging-ikuspegia aplikatzen duen esku-hartze pedagogikoa du ardatz. Translanguagingean oinarritutako proiektu pedagogikoa Euskal Autonomia Erkidegoko ikastetxe publiko batean garatu zen. Ikastetxeak D ereduan irakasten du; beraz, euskara da irakats-hizkuntza eta gaztelania eta ingelesa ikasgai moduan jasotzen dituzte. Esku-hartzea 2015eko otsaila eta maiatza bitartean garatu zen, eta orotara 12 asteko iraupena izan zuen. Esku-hartzean erabiltzeko berariazko material didaktikoak sortu ziren, aurretiaz nazioartean eginiko esperientzien azterketa sakona egin eta, horretaz gain, eskolaren metodologia propioa ere kontuan hartuz. Amara Berri sareko ikastetxea izaki, sistemaren ezaugarri metodologikoetara moldatu zen proiektu pedagogikoa. Esku-hartzearen aurretik formazio saioak burutu ziren irakaslearekin material didaktikoaren nondik norakoak azaltzeko (esku-hartzearen inguruan gehiago sakontzeko, ikus, Cenoz, Leonet eta Saragueta, 2019; Leonet, Cenoz eta Gorter, 2017).

Materialen izaerari dagokionez, guztira sei ikasle-liburuxka sortuko ziren, bi liburuxka ikasgai bakoitzerako. Liburuxka bakoitzean jarduera-sekuentzia bat aurkeztu zen, zeinak amaierako produktu bat gauzatzea zuen azken xedea. Produktu hauek hainbat formatu (idatzizko testuak, irratiko programak, dokumentalak, ahozko aurkezpenak, eta abar), prozedura eta baliabide material erabiliz sortu zituzten ikasleek, bakarkako lana eta taldekoa tartekatuz; eta, azkenik, ikastetxeko irratian, telebistan edota prentsan argitaratu ziren, burututako lana komunitate guztiari zabalduz. Liburuxka 
bakoitzeko jarduera-sekuentzia sortzeko ikastetxeko programazioaren ezaugarriak eta espazio-denbora antolaketa kontuan izan ziren, baina ariketak erdiesteko bi edo hiru hizkuntza erabiltzea proposatu zen translanguaging-ikuspegi pedagogikoan oinarrituz. Adibideren bat jartzearren, «Lumaren kilimak» izeneko liburuxkan hainbat testu-generotako idatzizko produkzioak ekoitzi eta haien arteko antzekotasunak eta desberdintasunak azpimarratzen ziren. Kontestua euskarako ikasgaian egon arren, ikasleek hiru hizkuntzetan idatzi zituzten ipuinak, eta azken produkzioak egin aurretik zirriborroak eta eskemak nahi zuten hizkuntzan egiteko aukera eman zitzaien. Gaztelaniako ikasgaiko «Radio y TV» liburuxkan, aldiz, beste hainbat jardueraren artean, herriko paisaia linguistikoa aztertu zuten ikasleek. Horren helburua, batetik, hizkuntzekiko kontzientzia garatzea zen, edo, zehatzago esanda, haien herriko hizkuntza-aniztasuna azaleratzea. Beste helburu bat ikasleen kontzientzia metalinguistikoa garatzea zen, herriko paisaia linguistikoan topatutako hitz eratorri eta konposatuekin jolastuz, eta hiru hizkuntzetan baliokideak dituzten hitzak identifikatzen irakatsiz. Adibidez, euskarazko «liburu-denda» eta ingelesezko «bookshop» hitz konposatuak modu berean sortzen direla ikasi zuten ikasleek, baina gaztelaniazko «librería» sortzeko atzizkia erabiltzen dela. Gainera, ariketa xume honek, hitz sasi-adiskideez ohartarazteko aukera eskaintzen du, gaztelaniazko «librería» eta ingelesezko «library» hitzaren esanahia bereiziz.

Laburbilduz, ikerketa honetan hiru hizkuntzen (euskara, gaztelania eta ingelesaren) arteko antzekotasunak azaleratzen dituzten ariketen bidez, hizkuntza-baliabideen erabilera alderatze hutsetik haratago joan, eta baliabide hauen erabilera estimulatzen duen esku-hartze didaktikoak izan dezakeen eragina egiaztatu nahi izan dugu, hizkuntza gutxitua hizkuntza indartsuagoekin bizi den hezkuntza testuinguru honetan.

Arestian aipatutako oinarrizko helburu horri erantzuteko, ikerketa galdera honek gidatu du ikerketa hau:

IG-1. Izan al du eraginik ikasleen euskara-mailan hiru hizkuntzak integratzen dituen interbentzio pedagogikoak?

\section{METODOLOGIA}

\section{Parte-hartzaileak}

Ikerketa hau Euskal Autonomia Erkidegoko ikastetxe publiko batean egin da, eta Lehen Hezkuntzako 5. eta 6. mailako 89 ikaslek parte hartu dute (adina 10,68). Horietatik 47 talde esperimentalekoak dira, hots, translanguagingean oinarritutako esku-hartzean parte hartu duten ikasleak. Taldeen arteko konparaketa egiteko asmoz, gainerako 42 ikasleek kontrol- 
taldea osatzen dute. Parte-hartzaileen sexu-banaketari dagokionez, \% 58,4 emakumezkoak eta \% 41,6 gizonezkoak dira. Parte-hartzaileen \% 55,3rentzat gaztelania da etxeko hizkuntza nagusia, \% 28,2rentzat euskara eta $\%$ 16,5ek bi hizkuntzetan hitz egiten dute etxekoekin.

Ikerketa honetan parte hartu duen irakasleak esku-hartze pedagogikoan ere parte hartu zuen. Bi ikasgeletan gaztelania eta euskara irakatsi zituen esku-hartzerako prestatutako materialak erabiliz. Euskara eta gaztelanian maila altua izateaz gain, maila aurreratua zuen ingelesean ere (Erreferentziazko Europar Markoaren arabera, B2 maila). Irakasle lanetan esperientzia luzea zuen eta 10 urtetik gora zeramatzan eskola horretan lanean.

\section{Tresnak eta prozedura}

Ikerketa honetan metodologia kuantitatiboa eta kualitatiboa erabili ziren. Hauek dira hiru ikerketetan erabilitako iker-tresnak eta datu-bilketan jarraitutako prozedurak:

Ikasleen oinarrizko informazioa biltzeko galdetegia. Aldagai indibidualak nahiz inguruneari dagozkionak neurtzeko galdetegi bat pasa zitzaien ikasle guztiei interbentzioaren aurretik. Besteak beste, honako informazio hau bildu zen: lehenengo hizkuntza, sexua, adina, familiako hizkuntza, konpetentzia eleanitzaren pertzepzioa.

Euskaraz irakurriaren ulermena neurtzeko testa. ISEI-IVEIek sortutako test estandarizatua egin zuten ikasle guztiek interbentzioaren aurretik eta ondoren. Testak Ebaluazio Diagnostikoa egiteko erabili ohi diren tresnen ezaugarriak zituen. Honen xedea zen ikasleek euskaraz irakurriaren ulermenean izandako garapena ezagutzea. Testak ISEI-IVEIek ebaluazio-diagnostikoan erabiltzen dituen testen ezaugarri berdinak zituen. Testak aukera anitzeko 24 item zituen pre-testean, eta 21 item post-testean. Item bakoitzak lau erantzun posible eskaintzen zituen. Testak betetzeko, ikasleak bost taldetan multzokatu ziren. Ikasle bakoitzak 40 minutu izan zituen testa bakarka burutzeko. Ikasle guztiek argibide berberak jaso zituzten aurrez formatutako DREAM eta ISEI-IVEIko bost ikertzaileen eskutik. Analisiak egiteko, SPSS-21 programa informatikoa erabili zen (Testaren zehaztasun gehiago nahi izanez gero, ikus doktore-tesi argitaragabea ${ }^{2}$.

Erdi-gidatutako elkarrizketa. Esku-hartzean parte hartu zuen irakasleak translanguagingean oinarritutako esku-hartze didaktikoaz zuen jarrera aztertzeko berariazko protokolo bat sortu zen. Erdi-gidatutako elkarrizketaren bidez, translanguagingean oinarritutako proiektuari buruzko 24 galdera ireki egin ziren honako egitura honi jarraituz: sarrera, hizkuntza

${ }^{2}$ Leonet, O. (2018). «Focus on Multilingualism» eta bere aplikazio didaktikoa eskola testuinguruan. Doktore-tesi argitaragabea. Euskal Herriko Unibertsitatea (UPV/EHU). 
jarrerak, translanguaging esku-hartzea, ikasleak eta ixteko galdera. Elkarrizketa euskaraz egin zen, eta 46 minutu iraun zuen. Elkarrizketaren grabazioa transkribatu eta informazioa sailkatu egin zen honako hiru multzo hauetan: 1) translanguaging-ikuspegia eta proiektuari buruzko iritzi orokorra 2) hizkuntzen arteko mugak lausotzea, eta 3) translanguaginga eta euskararen garapena.

\section{EMAITZAK}

Ikerketa-galderari erantzunez, esku-hartze pedagogikoak ikasleen euskarazko irakurriaren ulermenean izandako eragina aztertuko dugu. Esku-hartzeak iraun zuen bitartean talde bakoitzak izandako garapena aztertzeko T probak egin ziren. Emaitzek erakutsi zuten bai talde esperimentalak ( $\mathrm{M}=57,18, \mathrm{DT}=17.10$-tik $\mathrm{M}=66.05$, $\mathrm{DT}=16,12$-ra $)$, bai kontrol-taldeak $(\mathrm{M}=62,30, \mathrm{DT}=17,67$-tik $\mathrm{M}=70,06, \mathrm{DT}=14.50$-ra $)$, biek, emaitza hobeak eskuratu zituztela esku-hartze aldiaren ostean; eta bi taldeen kasuan, aurre-testean eta post-testean eskuratutako puntuazioen arteko aldea estatistikoki esanguratsua zela, gainera (ikus, 1. taula).

\section{1. taula}

Talde esperimentalak eta kontrol-taldeak lortutako batez besteko puntuazioak desbideratze tipikoak, $T$ balioa eta adierazkortasuna euskarazko irakurriaren ulermena neurtzeko testean

\begin{tabular}{lcccc}
\hline & $\begin{array}{c}\text { Aurre-testa } \\
\text { Batezbestekoa } \\
(\mathrm{DT})\end{array}$ & $\begin{array}{c}\text { Post-testa } \\
\text { Batezbestekoa } \\
(\mathrm{DT})\end{array}$ & $\mathrm{T}$ & Adieraz. \\
\hline Talde esperimentala & $57,18(17,10)$ & $66,05(16,12)$ & $-4,07$ & $\mathbf{. 0 0}$ \\
Kontrol-taldea & $62,30(17,67)$ & $70,06(14,50)$ & $-3,03$ & $\mathbf{. 0 0}$ \\
\hline
\end{tabular}

Esku-hartzeak izandako eragina ikusteko, kobariantza-analisia burutu zen. Aldagai askea translanguaging-esperientzia izan zen (talde esperimentala/kontrol-taldea) eta menpeko aldagai modura post-testean lorturiko puntuazioak erabili ziren. Kobariantza, berriz, aurre-testean lorturiko puntuazioak ziren. Aurretiazko egiaztapenak egin ziren interakziorik ez zela ziurtatzeko. Hasierako balizko ezberdintasunak eragindako efektuak kontrolatu ostean, ez zen ezberdintasun estatistikoki adierazgarririk antzeman talde esperimentalaren eta kontrol taldeko emaitzen artean $(\mathrm{F}(1,86)=.07, p=.77$, eta karratu partziala $=.00)$. Gainera, harreman estua zegoen aurre-testean lortutako puntuazioaren eta post-testeko puntuazioaren artean .75 eta karratu partzialak adierazi bezala. 
1. irudian ikus daitekeen moduan, kontrol-taldeak emaitza hobea eskuratu zuen bai esku-hartzearen aurretik bai eta esku-hartzearen ondoren ere. Hala ere, taldeen arteko aldea puntu bat pasatxo murriztu zen aurre-testetik post-testera. Bi taldeen arteko aldea aurre-testean 8,87 puntukoa izan zen; post-testean, berriz, bi taldeen arteko aldea 7,76 puntura murriztu zen. Dena den, Ancova analisiak erakutsi bezala, alde hau ez da estatistikoki esanguratsua.

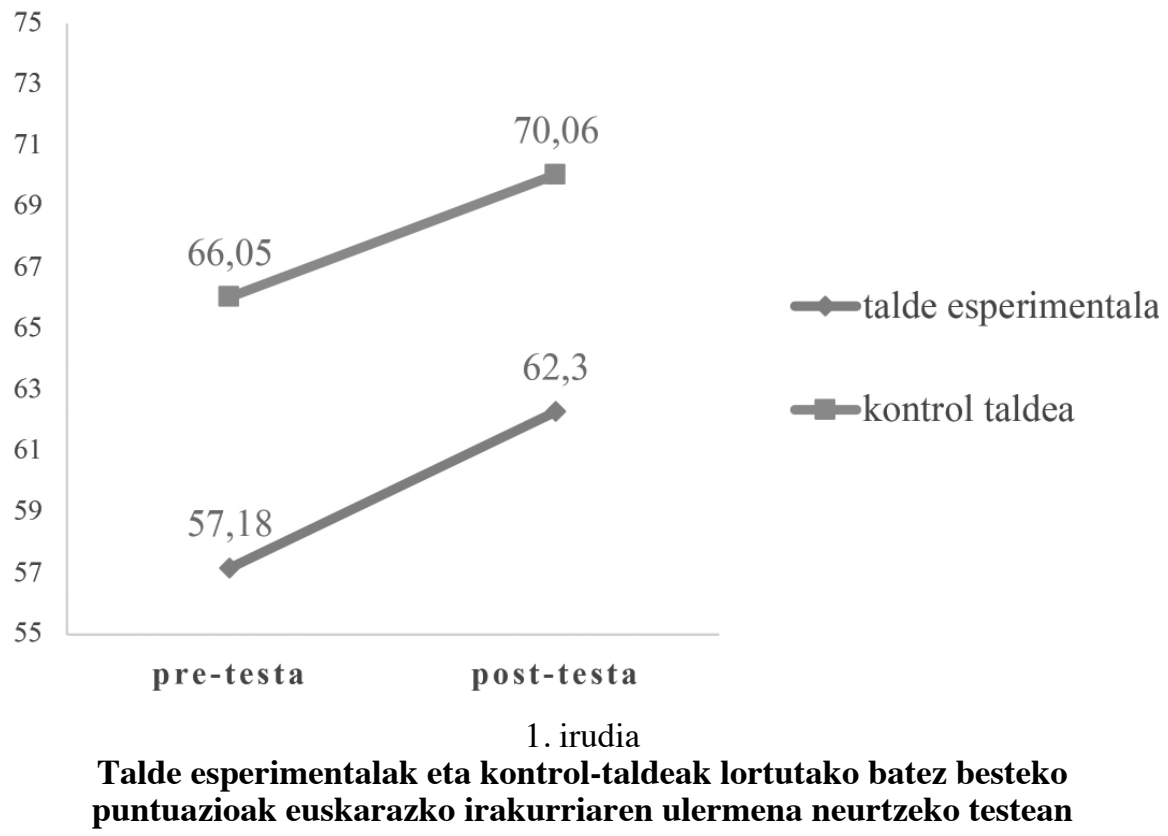

Translanguaging pedagogikoaren eta euskara mantentzeko eta berpizteko xedearen arteko orekaz zertxobait sakondu asmoz, esku-hartzean parte hartu zuen irakasle baten iritziak jaso genituen. Oro har, irakasleak proiektu pedagogikoa arrakastatsua izan zela iradokitzen du. 1. pasartean, translanguaging-ikuspegiak proposatzen dituen hainbat ideia lehenago ere ikasgelan erabiltzen zituela adierazten du irakasleak, baina oso modu positiboan baloratzen du ikuspegi elebakarra alde batera utzi eta modu sistematikoan eta planifikatuan ikasleen hizkuntza-errepertorio zabalarekin lan egiteko interbentzioak eskaintzen duen aukera. Gainera, aitortzen du esku-hartzerako sortutako zenbait proposamen didaktiko aproposak izan daitezkeela ikastetxearen curriculumean txertatzeko. 


\section{1. pasartea}

Elkarrizketatzailea (El): Zer iruditu zaizu proiektua?

Irakaslea (Ir): Gainera, hori, lehengoan komentatu genuen gauza, batzuk intuitiboki guk urteetan egiten genbiltzanak, hizkuntza bateko ezagutzak erabili beste hizkuntza bateko ezagutzak errazteko, lotzeko eta aurkezteko ... era sistematiko batean landu dira. Beste alde batetik, berritzailea da, zergatik duela urte batzuk esaten ziren gauzekin apur bat apurtzen du, eta alde horretatik interesgarria iruditu zait. Eta hori, era sistematiko batean eta aurretik hausnartua eta bideratua, ba beti da askoz hobea. (...) Ni eroso sentitu naiz. Presioa izan da, datak ... baina, beste alde batetik oso interesgarria eta aberasgarria iruditu zait. Zuen txostenetan planteatu dituzuen hainbat lan gure curriculumean erabili ahal ditugula uste dut nik.

2. pasartean ikasleak material berriekin lan egiteko jarrera positiboa erakutsi zutela eta ikuspegi berrira nahiko erraz moldatu zirela gaineratzen dio, eta ikasleek egindako hainbat aurrerapen azpimarratzen ditu:

\section{2. pasartea}

El: Esango zenuke alde positiborik edo negatiborik?

Ir: Umeak nahiko motibatuta ikusi ditudala. Hasiera batean batzuk nahastu baziren ere, gero joan zirela lasaitzen eta apur bat martxa hartzen. Eurentzat ez dela izan hain gauza arraroa, edo ezinezkoa, edo logikarik ikusten ez ziotena. Ez! Sartu dira proiektuan oso erraz eta gustura. (...) Hiztegi berria ikasteko aukerak eman dizkie: konposatuak, sustraikideak, eratorriak ... hizkuntza guztietan zelan egiten diren. Antolatzaileak, ipuinen hasierak, amaierak ... Eskemak ere lagundu die asko ipuinak eta testuak idazten. Hor hartu dugu sorpresa; onak, nire ustez, oso onak.

Esku-hartzean hizkuntzen arteko mugak bigundu egin ziren, eta euskara, gaztelania eta ingelesa hiru hizkuntza ikasgaietan erabili ziren translanguagingean oinarritutako ariketetan. Irakasleak aipatzen duenez, bereziki arrakastatsuak izan ziren hiztegiaren garapenari loturako estrategia metalinguistikoak.

\section{3. pasartea}

El: Nolako loturak egiten dituzte batez ere? Nolako transferentziak?

Ir: Ulermenean, hitz sustraikideak eurentzat izan dira deskubrimendu bat. Eta ume batzuk, azkenean taldeka eta binaka lan egiteko zailtasunak dituztenak, gauza batzuk bakarrik egin dituzte eta gai izan dira, nahiz eta 5. mailakoak izan hitz sustraikideak eta ingeleseko testuetatik eta ateratzeko. Eta gero, eratorrien eta konposatuen arteko hori, hiru hizkuntzetan zelan jokatzen duten ere. 
Hiztegiaz gain, 4. pasartean ikus dezakegun moduan, irakasleak modu positiboan baloratu zituen idatzizko ekoizpenak egitera bideratutako materialetan hainbat hizkuntza erabiltzeko proposamena. Ikasleek aurrez zehaztutako hizkuntza batean azken ekoizpena egin aurretik, aukera eskaini zitzaien ideiak antolatzeko zirriborroa egiteko nahi zuten hizkuntza erabiltzeko.

\section{4. pasartea}

Ir: sorpresa izan da batzuek nola aukeratu duten euskara gaztelaniako eskemak egiteko, hau da, gero gaztelaniaz ekoizteko. Guk pentsatzen genuen eskema ere gaztelaniaz egingo zutela eta batzuek ez. Eta eurek normaltasunez egin dute eta nik ez dut uste hizkuntza kaltetua atera dela horregatik. Ez dut ikusi euskarakada edo erdarakada berezirik. Eta ingeleseko kasuan beharbada beharrezkoa ikusi dut, ze eurentzat ingelesezko testuak ekoiztea oraindik zaila da eta eskemak egin ahal izatea eta askok aukeratu dute euskara edo gaztelania eskema egiteko, oso gutxik aukeratu dute ingelesa eskema egiteko. Eurentzat oso lagungarria izan da gero testua burutzeko.

Ikasleek hizkuntzen artean egiten zituzten transferentzien inguruan galdetu zitzaion irakasleari. Honen arabera, ikasleen errendimenduan aldeak egon baziren ere, ikasleek hiru hizkuntza-ikasgaietan ikasitako edukien artean loturak egiten zituztela antzeman zuen; hots, ikasgai batean ikasitakoa beste ikasgaietan ikasitakoa bere ikasgaian erabiltzen zutela adierazi zuen (ikus, 5. pasartea).

\section{5. pasartea}

El: uste duzu ikasleek erabiltzen dituztela beren hizkuntzetako aurrezagutzak gauza berriak ikasteko? Hau da hizkuntzetako eduki berriak ikasteko?

Ir: nik uste dut baietz. Hausnarketa egiten ohituta edo gogoa dutenek bai. Beste batzuek ez. Lan egiteko moduan murgildu direnek eta ahalegindu direnek bai. (...) Nik uste dut baietz eta eurek ere komentarioak egin dituzte horretaz, konturatu dira hitz batzuetan. Honela egiten dugu gaztelanian eta ingelesean, eta hau horrela doa eta egiten dituzte horrelako komentarioak. Bai, egiten dituzte transferentziak, batzuetan ez dira egokiak ere.

Hiru hizkuntzen aldi bereko erabilerak nolabaiteko kezka ere sortzen du irakaslearengan, batez ere euskara eta hizkuntza indartsuagoen arteko elkarbizitzari lotuta. Irakasleak gaztelaniaren nagusitasuna eta ingelesaren prestigioa aipatzen ditu. Haren arabera, ikasleak dagoeneko jabetzen dira ingelesari gizartean ematen zaion garrantziaz, eta motibazio handiagoa erakusten dute zenbaitek hizkuntza horren aurrean (ikus 6. pasartea). 


\section{6. pasartea}

Ir: Eta lider batzuek hartu dute hau ingelesetik. Haiek uste dute euskara oso ondo dakitela, eta gehiago zertarako? Orduan hartu dute ingelesa aberasteko modu bezala. Denbora asko behar duzu lan hori egiteko, eta hausnartu... eta sarritan denboraz larri ibiltzen gara.

Hala ere, irakasleak iradokitzen du kasu batzuetan hiru hizkuntzak batera lantzea euskarari prestigioa emateko modu bat izan daitekeela; izan ere, hiru hizkuntzak elkarrekin ikusteak besteen pare jarriko luke hizkuntza gutxitua.

\section{7. pasartea}

Ir: (...) Eta orduan ikustea horrela parekatuta, niretzat, eman zion bere garrantzia. Gero, ikusi dute L2an euskarazko presentzia dagoela ere, ingelesean ere bai, eta horrek ere eman dio euskarari bere presentzia.

Arestian aipatu bezala, translanguaging-proiektuaren helburuetako bat ikasleek hizkuntzen aurreko kontzientzia areagotzea zen. Hori kontuan izanda, hainbat materialetan ikasleek euren testuinguru hurbilaren analisi soziolinguistikoa egiteko aukera izan zuten. Irakasleak bereziki baloratu zuen materialek gelako hizkuntza-aniztasunaz eta zehazki euskararen egoeraz hausnartzeko eskainitako aukera.

\section{8. pasartea}

Ir: hizkuntzen alde soziologikoa asko landu dugu, horretarako aukera eman digu. Guk noizean behin zertzelada batzuk ..., baina ez daukagu finkatuta eta antolatuta, eta honekin bai, eta hori niri iruditu zait oso-oso interesgarria. Ume batzuei oso ondo etorri zaie hori, beren hizkuntzen mundua argitara izatea, plazaratzea, ikustea beste batzuk ere ez dabiltzala beti eskaraz eta erdaraz, badaudela beste hizkuntza batzuk. Horri buruz lanketa egitea ba oso-oso interesgarria da. (...) Eta gero asko jo dugu balorazioetan hizkuntza gutxituak eta euskararen egoerara. Igual behartu egin ditut asko horretara, baina uste nuen horretaz eurek behar zutela hausnarketa bat, eta egokia iruditu zait. Ze bestela joaten ziren asko ingelesera eta ... ba ondo, baina, prestigioa horrek badauka dagoeneko euren eguneroko bizitzan. Ume askok erabiltzen dute euskara irakasleekin gela barruan, gero ya kanpoan... ez daukate ez familia [euskalduna] ez giroa.

\section{EZTABAIDA ETA ONDORIO NAGUSIAK}

Translanguaingean oinarritutako irakaskuntza-metodologiek ikasleen komunikazio-gaitasuna garatzen lagundu dezaketela diote adituek, euren 
baitan dituzten errekurtso guztiak erabiltzeko aukera eskaintzen baitzaie ikasleei horrela. Hain zuzen ere, translanguaging-ikuspegiak proposatzen duen ideiak parekotasun handiagoa du hiztun eleaniztunek egunerokoan egiten duten hizkuntza-erabilerarekin, elebakartasunean oinarritutako hizkuntza-bereizketak baino (Cenoz eta Gorter, 2015; Cummins, 2017; García eta Li Wei, 2014).

Ikerlan honen ardatz den esku-hartze pedagogikoak ideologia elebakarra baztertu nahi izan du eta, aldi berean, ikasleen artean euskararen erabilera sustatzeko helburuarekin bat egiten du. Esku-hartze honek ikasleen euskara-mailan izandako eragina aztertzeko asmoz, ikasleen irakurriaren ulermena neurtu da esku-hartzearen aurretik eta ondoren. Analisi kuantitatiboetatik ateratako emaitzek ez dute bi taldeen arteko desberdintasunik erakutsi euskarako irakurriaren ulermena neurtzeko proban. Emaitza hauek kontuan izanik, ezin dugu esan translanguaging-ikuspegia oinarri harturik sortutako materialek ikasleen euskarazko irakurriaren ulermena hobetzen lagundu dutenik. Aurkikuntza honek, hala ere, badu bere garrantzia, agerian uzten baitu helburu pedagogikoekin, hiru hizkuntzen erabilera malgua egiteak ez duela ikasleen euskara-mailan kalterik eragin.

Oro har, positiboa izan da irakasleak material hauen bidez irakatsi ostean emandako feedbacka. Elkarrizketan, batetik, ikasgelan hizkuntzak nahasteari buruz galdetu zitzaion. Irakasleak, translanguagingean oinarritutako jarduera didaktikoek ikasleen kontzientzia metalinguistikoa eta irakurketaidazketa gaitasunak garatzeko tresna baliagarriak direla adierazi zuen. Honen arabera, bereziki arrakastatsuak izan ziren hitz sustraikideak identifikatzeko estrategiak eta hitz eratorri eta konposatuekin egindako ariketak. Beste eskuhartze ikerketa batzuek ere emaitza positiboak aurkitu dituzte morfologiaren eta hitz sustraikideen irakaskuntza esplizitua hizkuntza arteko ikuspegitik landu ostean (Arteagoitia eta Howard, 2015; Lyster et al., 2013). Era berean, Lyster eta haren kideek (2009) aurkeztutako proposamenaren ildotik, ikerketan parte hartu zuen irakaslearen arabera, ikasleek modu positiboan eta motibazio handiz erantzun zuten material berrien aurrean.

Bestetik, irakasleak euskararen egoeraren aurrean kezka azaldu zuen gaztelaniaren eta ingelesaren prestigioaren aurrean. Zentzu honetan, irakaslearen feedbackak bat egiten du Cenoz eta Gorterren (2017a) iritziarekin, euskarari hizkuntza indartsuagoekin lehiatu beharrik ez duen espazioak gorde behar zaizkiola, alegia (ikus, era berean, García, 2009). Cenoz eta Gorterren arabera, ikasleen konpetentzia eleaniztuna garatzea helburu duen esku-hartze batek, gurea bezalako testuinguru eleaniztunetan, ikastetxearen ezaugarri soziolinguistikoak kontuan izan behar ditu ezinbestean. Proiektuaren diseinuan oso kontuan izan zen euskal hezkuntza-sistemak euskararen mantentze eta biziberritzean duen konpromisoa. Sortutako materialak kontu handiz diseinatu eta planifikatu ziren, translanguaging-ikuspegiaren barruan sortutako esku-hartzeak euskara erabiltzeko berariazko espazioak eskaini zitzan. 
Irakasleak, gainera, bereziki baloratzen du materialek hausnarketa soziolinguistikoa egiteko eskaintzen duten aukera. Euskara gure lurraldean hizkuntza ofiziala eta, gaur egun, instrukzio-hizkuntza nagusia izan arren, irakasleak argi adierazten du ikasleen artean duen presentzia eskasa eta prestigio urrikoa dela. Hain justu, irakasle honen ekarpen interesgarri bat zera da, hiru hizkuntzak parez pare jarriaz eta tratamendu bera eskainiaz hizkuntza gutxituari prestigioa eman zitzaiola. Bestetik, curriculumeko hizkuntzen artean dagoen estatus-desorekari erantzuteko, ikasleen hizkuntzen aurreko kontzientzia garatzeko beharra ere azpimarratzen du. Irakaslearen arabera, euskararen inguruan gogoeta egiteko ez ezik, gelako ikasle etorkinen hizkuntzak ezagutzera emateko ere balio izan zuten materialek.

Horrenbestez, batetik, translanguaging pedagogikoa oinarri duen esperientzia honen balorazio positiboa egin dezakegu. Bestetik, emaitzak kontuan hartuz, oro har, esan dezakegu translanguaging-ikuspegia hizkuntza gutxituaren mantentze eta suspertzearekin bateragarria izan daitekeela. Dena den, ikerlanak ez ditu kontuan hartzen translanguaging espontaneoaren erabilera pedagogikoa eta haren eragina. Horretaz gain, ikerketa testuinguru zehatz batean burutu da, subjektu kopuru mugatu batekin.

Ikerketak bere mugak izan badituen arren, eta translanguaging esku-hartzeak Galesen egiten den translanguaging-ereduarekin lotura izan arren, zenbait berritasun aurkezten ditu. Batetik, norabide honetan orain arte egindako saiakera gehienek bi hizkuntza izan dituzte kontuan; esku-hartze honek, berriz, hiru hizkuntzen interakzio sistematikoa egiteko proposamena egiten du. Gainera, esku-hartzean zehar, hiru hizkuntzak erabiliz, estrategia eta jarduera sorta zabala aurkeztu zaie ikasleei translanguaging-ikuspegia eskolaren antolamendura eta metodologiara egokituz.

\section{ERREFERENTZIAK}

Arocena (2018). Euskararen eta gaztelaniaren erabilera ingeleseko irakaskuntzasaioetan. TANTAK, 30(1), 37-55. doi: http://dx.doi.org/10.1387/tantak.19825

Arocena, E., Cenoz, J., \& Gorter, D. (2015). Teachers' beliefs in multilingual education in the Basque country and in Friesland. Journal of Immersion and Content-Based Language Education, 3(2), 169-193. doi: http://dx.doi.org/10.1075/ jicb.3.2.01aro

Arteagoitia, I., \& Howard, E. R. (2015). The Role of the Native Language in the Literacy Development of Latino Students in the U.S. J. Cenoz, \& D. Gorter (Eds.), Multilingual Education: Between Language Learning and Translanguaging, (89-115). Cambridge: Cambridge University Press.

Blommaert, J., \& Rampton, B. (2012). Language and superdiversity. MMG Working Paper, 12-09. doi: http://hdl.handle.net/11858/00-001M-0000-000E-7CFE-9

Canagarajah, S. (2011). Translanguaging in the classroom: Emerging issues for research and pedagogy. Applied linguistics review, 2(1), 1-28. doi: https://doi. org/10.1515/9783110239331.1 
Cenoz, J., \& Gorter, D. (2011). Focus on multilingualism: A study of trilingual writing. The Modern Language Journal, 95(3), 356-369. doi: 10.1111/j.15404781.2011.01206.x

Cenoz, J., \& Gorter D. (2014). Focus on Multilingualism as an Approach in Educational Contexts. A. Blackledge, \& A. Creese (Eds.), Heteroglossia as Practice and Pedagogy. Educational Linguistics (Vol 20, 239-254). doi: https:// link.springer.com/content/pdf/10.1007\%2F978-94-007-7856-6_13.pdf

Cenoz, J., \& Gorter, D. (2015). Towards a holistic approach in the study of multilingual education. J. Cenoz, \& D. Gorter (Eds.), Multilingual Education: Between Language Learning and Translanguaging (1-15). Cambridge: Cambridge University Press.

Cenoz, J., \& Gorter, D. (2017a). Minority languages and sustainable translanguaging: threat or opportunity?. Journal of Multilingual and Multicultural Development, 38 (10), 901-912. doi: http://dx.doi.org/10.1080/01434632.2017.1284855

Cenoz, J., \& Gorter, D. (2017b). Translanguaging as a pedagogical tool in multilingual education. J. Cenoz, D. Gorter, \& S. May (Eds.) Language Awareness and Multilingualism. Encyclopedia of Language and Education ( $\left.3^{\text {rd }} \mathrm{ed}\right)$ (1-14). doi: 10.1007/978-3-319-02240-6_20

Cenoz, J., Leonet, O., \& Saragueta, E. (2019). Cruzando fronteras entre lenguas: una intervención didáctica. TEXTOS. Didáctica de la Lengua y de la Literatura, 84.

Conteh, J., \& Meier, G. (Eds.). (2014). The multilingual turn in languages education: Opportunities and challenges (Vol. 40). Bristol, UK: Multilingual Matters.

Creese, A., \& Blackledge, A. (2010). Translanguaging in the bilingual classroom: A pedagogy for learning and teaching?. The Modern Language Journal, 94(1), 103-115. doi: 10.1111/j.1540-4781.2009.00986.x

Cummins, J. (2007). Rethinking monolingual instructional strategies in multilingual classrooms. Canadian Journal of Applied Linguistics/Revue canadienne de linguistique appliquée, 10(2), 221-240. Retrieved from https://journals.lib. unb.ca/index.php/CJAL/article/view/19743/21428

Cummins, J. (2017). Teaching for transfer in multilingual school contexts. In O. García, A. Lin, \& S. May (eds.), Bilingual and Multilingual Education, Encyclopedia of Language and Education (103-115). Berlin: Springer, doi: 10.1007/978-3-319-02258-1_8

Extra, G., \& Gorter, D. (Eds.). (2008). Multilingual Europe: facts and policies (Vol. 96). Berlin: Walter de Gruyter.

Fishman, J. A. (1991). Reversing language shift: Theoretical and empirical foundations of assistance to threatened languages (Vol. 76). Clevedon, UK: Multilingual matters.

García, O. (2009). Bilingual Education in the 21st Century: A Global Perspective. Malden, MA and Oxford: Wiley/Blackwell.

García, O., \& Wei, L. (2014). Translanguaging: Language, Bilingualism and Education. New York: Palgrave Macmillan.

Gort, M., \& Sembiante, S. F. (2015). Navigating hybridized language learning spaces through translanguaging pedagogy: Dual language preschool teachers' languaging practices in support of emergent bilingual children's performance of academic discourse. International Multilingual Research Journal, 9(1), 7-25. doi: http://dx.doi.org/10.1080/19313152.2014.981775

Grosjean, F. (2008). Studying bilinguals. Oxford: Oxford University Press. 
Jones, B., \& Lewis, W. G. (2014). Language arrangements within bilingual education. W. G. Lewis, B. Jones, G. Lewis, \& E. M. Thomas (Eds.), Advances in the study of bilingualism, 141-170. Bristol: Multilingual Matters.

Jørgensen, J. N. (2005). Plurilingual conversations among bilingual adolescents. Journal of pragmatics, 37(3), 391-402. doi: https://doi.org/10.1016/j. pragma.2004.10.009

Kano, N. (2010). Translanguaging as a process and a pedagogical tool for Japanese students in an English writing course in New York (Doctoral dissertation). Teachers College, Columbia University. Retrieved from https://search. proquest.com/docview/1024428749?pq-origsite=gscholar

Kramsch, C. (2012). Authenticity and legitimacy in multilingual SLA. Critical Multilingualism Studies, 1(1), 107-128. Retrieved from https://cms.arizona. edu/ojs3/multilingual/article/view/9

Leonet, O. (2018). Focus on multilingualism» eta bere aplikazio didaktikoa eskola testuinguruan/Focus on multilingualism and its didactic application to the school context (Unpublished Doctoral dissertation). Universidad del País Vasco-Euskal Herriko Unibertsitatea (UPV/EHU).

Leonet, O., Cenoz, J., \& Gorter, D. (2017). Challenging Minority Language Isolation: Translanguaging in a Trilingual School in the Basque Country. Journal of Language, Identity \& Education, 16(4), 216-227. doi: https://doi.org/10.108 0/15348458.2017.1328281

Lewis, G., Jones, B., \& Baker, C. (2012a). Translanguaging: Origins and development from school to street and beyond. Educational Research and Evaluation, 18(7), 641-654. doi: http://dx.doi.org/10.1080/13803611.2012.718488

Lewis, G., Jones, B., \& Baker, C. (2012b). Translanguaging: Developing its conceptualisation and contextualisation. Educational Research and Evaluation, 18(7), 655-670. doi: http://dx.doi.org/10.1080/13803611.2012.718490

Li, W., \& Wu, C. J. (2009). Polite Chinese children revisited: Creativity and the use of codeswitching in the Chinese complementary school classroom. International Journal of Bilingual Education and Bilingualism, 12(2), 193-211. doi: http://dx.doi.org/10.1080/13670050802153210

Llurda E., Cots J.M., Armengol L. (2013). Expanding Language Borders in a Bilingual Institution Aiming at Trilingualism. H. Haberland, D. Lønsmann, B. Preisler (Eds.), Language Alternation, Language Choice and Language Encounter in International Tertiary Education (pp. 203-222). doi: https://doi. org/10.1007/978-94-007-6476-7_10

Lowman, C., Fitzgerald, T., Rapira, $\bar{P}$., \& Clark, R. (2007). First language literacy skill transfer in a second language learning environment: Strategies for biliteracy». Set, 2, 24-28.

Lyster, R., Collins, L., \& Ballinger, S. (2009). Linking languages through a bilingual read-aloud project. Language Awareness, 18, 366-83. doi:10.1080/09658410903197322

Lyster, R., Quiroga, J., \& Ballinger, S. (2013). The effects of biliteracy instruction on morphological awareness. Journal of Immersion and Content-Based Language Education, 1(2), 169-197. doi: http://dx.doi.org/10.1075/jicb.1.2.02lys

Martin-Beltrán, M. (2014). 'What do you want to say?' How adolescents use translanguaging to expand learning opportunities. International Multilingual Research Journal, 8(3), 208-230. doi: http://dx.doi.org/10.1080/19313152.2014.914372 
May, S. (Ed.). (2013). The multilingual turn: Implications for SLA, TESOL, and bilingual education. New York: Routledge.

Moore, D., \& Gajo, L. (2009). Introduction-French voices on plurilingualism and pluriculturalism: theory, significance and perspectives. International Journal of Multilingualism, 6(2), 137-153. doi: http://dx.doi. org/10.1080/14790710902846707

Musk, N. (2010). Code-switching and code-mixing in Welsh bilinguals' talk: confirming or refuting the maintenance of language boundaries?. Language, culture and curriculum, 23(3), 179-197. doi: http://dx.doi.org/10.1080/07908 318.2010 .515993

Osterkorn, P., \& Vetter, E. (2015). Le Multilinguisme en Question? The Case of Minority Language Education in Brittany (France). U. Jessner, \& C. Kramsch (Eds.), The Multilingual Challenge: Cross-Disciplinary Perspectives, 16, 115 139. Berlin: Walter de Gruyter, Inc.

Otheguy, R., García, O., \& Reid, W. (2015). Clarifying translanguaging and deconstructing named languages: A perspective from linguistics. Applied Linguistics Review, 6(3), 281-307. doi: https://doi.org/10.1515/applirev-20150014

Sayer, P. (2012). Translanguaging, TexMex, and bilingual pedagogy: Emergent bilinguals learning through the vernacular. Tesol quarterly, 47(1), 63-88. doi: $10.1002 /$ tesq.53

Williams, C. (1994). Arfarniad o Ddulliau Dysgu ac Addysgu yng Nghyddestun Addysg Uwchradd Ddwyieithog, [An evaluation of teaching and learning methods in the context of bilingual secondary education] (Unpublished Doctoral Thesis). University of Wales, Bangor.

Zarraga, A. (2014). Hizkuntza-ukipenaren ondorioak. Webgune honetatik berreskuratua: http://www.erabili.eus/zer_berri/muinetik/1410777403/1410864140 